\title{
Toxin profile of Alexandrium tamarense (Dinophyceae) from Hokkaido, northern Japan and southern Sakhalin, eastern Russia
}

\author{
Hiroshi Shimada ${ }^{1, *}$, Irina Victorovna Motylkova ${ }^{2}$, TAtyana AleXandrovna Mogilnikova ${ }^{2}$, \\ KanAKO MiKAMI $^{1} \&$ MinORU KimUra ${ }^{1}$ \\ ${ }^{1}$ Central Fisheries Research Institute of Hokkaido Research Organization, Hamanaka-cho 238, Yoichi, Hokkaido 046-8555, \\ Japan \\ ${ }^{2}$ Sakhalin Scientific Research Institute of Fisheries and Oceanography, Komsomol'skaya Street 196, Yuzhno-Sakhalinsk 693023, \\ Russia
}

Received 8 July 2010; Accepted 24 November 2010

\begin{abstract}
To evaluate the variations in the toxin profiles of Alexandrium tamarense (Dinophyceae) from Hokkaido and southern Sakhalin, paralytic shellfish poison of 103 culture strains obtained from six areas (Funka Bay, Tomakomai, Urakawa, Akkeshi, Okhotsk Sea and Aniva Bay) was analyzed using high performance liquid chromatographyfluorescent detection. All of the strains, except for two culture strains, were classified by a hierarchical cluster analysis into clusters in which the strains had almost the same toxin composition as found in previous studies (major toxins: $\mathrm{C} 2$, gonyautoxin 4, neosaxitoxin and gonyautoxin 3). On the other hand, cellular toxin contents of the culture strains varied from 1 to $1,128 \mathrm{fmol} \mathrm{cell}^{-1}$ and the cellular toxin content $\left(\mathrm{y} \mathrm{fmol} \mathrm{cell}{ }^{-1}\right.$ ) was inversely proportional to the cell density $\left(\mathrm{x}\right.$ cells $\left.\mathrm{mL}^{-1}\right)\left(\mathrm{y}=9942.2 \mathrm{x}^{-0.448}\right.$, Spearman's rank correlation coefficient: $\left.r_{s}=0.539, p<0.01\right)$. It can be concluded that the toxin compositions of $A$. tamarense are almost the same in Hokkaido and southern Sakhalin, and hightoxicity blooms of $A$. tamarense as usually found possibly occur in the natural environment at low cell densities $\left(10^{-2}-10^{2}\right.$ cells $\left.\mathrm{mL}^{-1}\right)$.
\end{abstract}

Key words: Alexandrium tamarense, Hokkaido, paralytic shellfish poison, Sakhalin, toxin profile

\section{Introduction}

The toxic dinoflagellate, Alexandrium tamarense (Lebour) Balech, has been recognized as a major causative organism of paralytic shellfish poisoning (PSP) throughout the world (Hallegraeff 1993). It is reported that $A$. tamarense occurs in coastal waters from the Pacific Ocean to the Okhotsk Sea in Hokkaido, and a large number of cysts of $A$. tamarense were found in the bottom sediments in the regions where PSP occurrences have been frequently recorded (Shimada \& Miyazono 2005). It was found that Ctoxin, gonyautoxin (GTX), neosaxitoxin (neoSTX) and saxitoxin (STX) were detected from culture strains of $A$. tamarense (e.g. Kaga et al. 2006), and the toxin compositions that varied among strains were inherited following the Mendelian rules (Sako et al. 1995). Recently, Nagai et al.

* Corresponding author: Hiroshi Shimada; E-mail, shimada-hiroshi@ hro.or.jp
(2007) revealed that several diverse populations can be identified in A. tamarense collected along the coast of Japan using microsatellite markers, and inferred that gene flow has possibly occurred among the populations due to human-assisted dispersal (e.g. shipping of bivalve spat). Hallegraeff (1995) pointed out that dinoflagellate cells can be and have been dispersed by ballast water in ships. From these reports, it is supposed that diverse populations of $A$. tamarense have a complex distribution pattern in Hokkaido, so that various populations with different toxin profiles may occur because bivalve culture, especially scallops, is a major industry along the coast of Hokkaido. Furthermore, it was suggested that $A$. tamarense blooms originate by the germination of cysts on the continental shelf from Hokkaido to Sakhalin in the Okhotsk Sea (Shimada et al. 2010). However, there is a paucity of information about the variation in toxin profiles and cellular toxin content of $A$. tamarense and their relation to the geographical distribution. If $A$. tamarense occurs in the fishing grounds for bi- 
valves, this information is important to allow estimation of the potential toxin composition and content in bivalves. The aims of the present study are to clarify and compare the toxin composition and the cellular toxin content among culture strains of $A$. tamarense isolated from sediments or seawater from Hokkaido and southern Sakhalin.

\section{Materials and Methods}

Bottom sediment or seawater samples for establishing culture strains of Alexandrium tamarense were collected at six areas from Funka Bay, southwestern Hokkaido to Aniva Bay, southern Sakhalin in August 2000-May 2009 (Fig. 1, Table 1). Sediment samples collected using a Smith-McIntyre or Ekman-Birge grab sampler were preserved in airtight containers at $3^{\circ} \mathrm{C}$ in a refrigerator. To obtain vegetative cells of $A$. tamarense from cysts, sieved samples

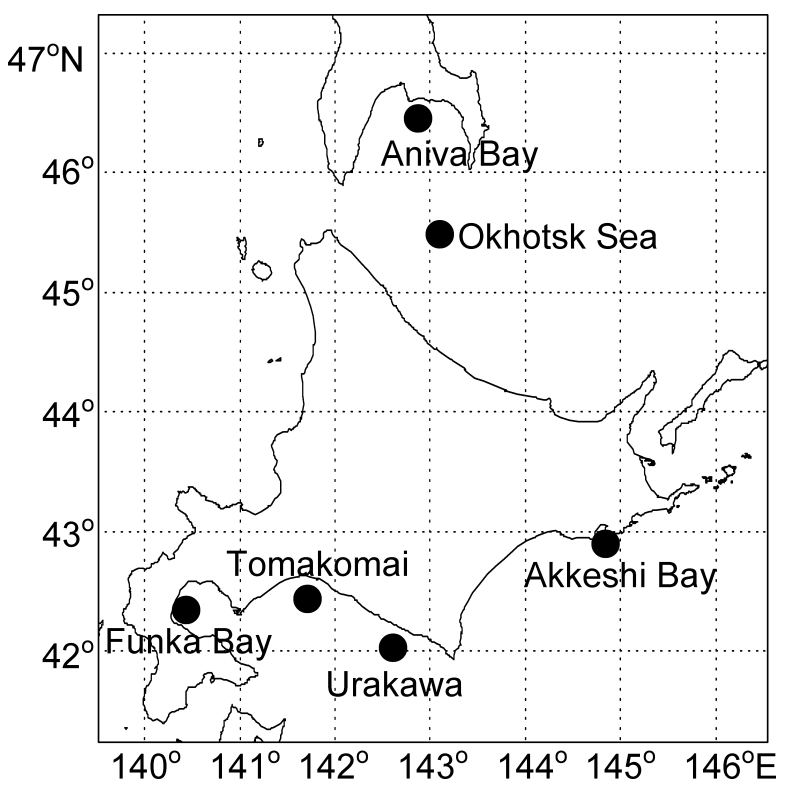

Fig. 1. Map showing the six sampling areas in Hokkaido and southern Sakhalin.
$(10-100 \mu \mathrm{m})$ of $2-3 \mathrm{~g}$ sediments were suspended with $100 \mathrm{~mL}$ of $\mathrm{GeO}_{2}$ - added, filtered seawater (final conc. $\left.1 \mathrm{mg} \mathrm{L}^{-1}\right)$, and $10 \mathrm{~mL}$ subsamples of the suspended samples were dispensed into culture plates (6 wells) and incubated for two weeks at $10^{\circ} \mathrm{C}$ under a $14 \mathrm{~h}: 10 \mathrm{~h}$ light: dark cycle with ca. $400 \mu \mathrm{mol}$ photons $\mathrm{m}^{-2} \mathrm{~s}^{-1}$ provided as white fluorescent illumination (color temperature $=5,000 \mathrm{~K}$ ).

For establishing clone cultures, vegetative cells of $A$. tamarense were washed with sterilized seawater using capillary pipettes and cultured for two weeks in $1 \mathrm{~mL}$ of SWIIm medium (Sako et al. 1990) dispensed into culture plates (48 wells) under the same conditions as mentioned above. Clone cultures were obtained after the $1 \mathrm{~mL}$ cultures were transferred into the $10 \mathrm{~mL}$ of SWIIm medium in test tubes and cultured for two weeks under the same conditions. Seawater samples were collected in Funka Bay using a Van-Dorn water sampler. Vegetative cells in the clone cultures obtained from the seawater were similarly washed and cultured as mentioned above. Axenic condition of the culture strains was not confirmed.

Identification of $A$. tamarense was performed on the basis of morphology after Balech (1995) under an epifluorescence microscope (XF-EFD2, Nikon, Tokyo, Japan) with UV excitation after calcofluor staining (Fritz \& Triemer 1985).

Subsamples of the culture in log phase or stationary phase (approx. 10 $10^{2}-10^{4}$ cells $\mathrm{mL}^{-1}$ ) were selected for toxin analysis. The $10 \mathrm{~mL}$ subsamples were centrifuged $(450 \mathrm{G}$, for $10 \mathrm{~min}$ ) and the supernatants were removed, and the cell pellets were fixed with acetic acid (conc. 0.5 M). Filtrate samples for high performance liquid chromatography-fluorescent detection (HPLC-FLD) were obtained after the fixed subsamples were sonicated using an ultrasonic homogenizer and then were centrifuged $(25,000 \mathrm{G}$, for $10 \mathrm{~min}$ ) and filtered through filter tubes (Ultrafree $\mathrm{C} 3 \mathrm{GC}$, Millipore, Massachusetts, USA) to remove high-molecularweight substances (MW >10,000). PSP were analyzed using HPLC-FLD (high pressure pump: L-6000, intelligent pump: L-6200, column oven: L-5030, fluorescent detector: F-1080, auto sampler: AS-2000, Hitachi, Tokyo, Japan) ac-

Table 1. List of sampling sites and culture strains.

\begin{tabular}{|c|c|c|c|c|c|c|c|}
\hline \multirow{2}{*}{ Area } & \multicolumn{2}{|c|}{ Location } & \multirow{2}{*}{$\begin{array}{c}\text { Source of } \\
\text { sample }\end{array}$} & \multirow{2}{*}{$\begin{array}{l}\text { Date of } \\
\text { sampling } \\
(\mathrm{d} / \mathrm{m} / \mathrm{y})\end{array}$} & \multirow{2}{*}{$\begin{array}{c}\text { Date of clone } \\
\text { culture established } \\
(\mathrm{d} / \mathrm{m} / \mathrm{y})\end{array}$} & \multirow{2}{*}{$\begin{array}{c}\text { Number of } \\
\text { culture strains } \\
\text { (abbreviated name in Fig. 3) }\end{array}$} & \multirow{2}{*}{$\begin{array}{c}\text { Research } \\
\text { vessel* }\end{array}$} \\
\hline & Latitude & Longitude & & & & & \\
\hline Funka Bay & $42^{\circ} 14.0^{\prime} \mathrm{N}$ & $140^{\circ} 16.0^{\prime} \mathrm{E}$ & bottom sediment & 24 Feb 2005 & 25 Jun 2006 & $16(\mathrm{FKS})$ & Boat \\
\hline Funka Bay & $42^{\circ} 14.0^{\prime} \mathrm{N}$ & $140^{\circ} 16.0^{\prime} \mathrm{E}$ & seawater & 24 May 2006 & 24 May 2006 & $10(\mathrm{FKW})$ & Boat \\
\hline Tomakomai & $42^{\circ} 29.9^{\prime} \mathrm{N}$ & $141^{\circ} 33.9^{\prime} \mathrm{E}$ & bottom sediment & 19 Apr 2005 & 23 Jun 2005 & 11 (TMS) & Kinsei Maru \\
\hline Urakawa & $42^{\circ} 07.8^{\prime} \mathrm{N}$ & $142^{\circ} 44.8^{\prime} \mathrm{E}$ & bottom sediment & 19 Apr 2005 & 23 Jun 2005 & 6 (URS) & Kinsei Maru \\
\hline Akkeshi Bay & $42^{\circ} 58.0^{\prime} \mathrm{N}$ & $144^{\circ} 49.0^{\prime} \mathrm{E}$ & bottom sediment & 8 Aug 2000 & 25 Jun 2007 & $30(\mathrm{AKS})$ & Boat \\
\hline Okhotsk Sea & $45^{\circ} 30.1^{\prime} \mathrm{N}$ & $142^{\circ} 49.8^{\prime} \mathrm{E}$ & bottom sediment & 27 May 2009 & 30 Jun 2009 & $10(\mathrm{OKS})$ & Hokuyo Maru \\
\hline Aniva Bay & $46^{\circ} 30.0^{\prime} \mathrm{N}$ & $142^{\circ} 54.0^{\prime} \mathrm{E}$ & bottom sediment & 28 Aug 2003 & 23 Jun 2005 & 20 (ANS) & Boat \\
\hline
\end{tabular}

* Boat: Light fishing boat $<20$ ton

Kinsei Maru: 151 ton, R/V of Hokkaido Hakodate Fisheries Research Institute

Hokuyo Maru: 237 ton, R/V of Hokkaido Wakkanai Fisheries Research Institute 
cording to the method of Oshima (1995). Cell densities of $A$. tamarense in the subsamples were estimated by counting the number of cells of $A$. tamarense in $0.1 \mathrm{~mL}$ of the culture under a microscope. Cellular toxin contents of the strains were calculated from the toxin contents and the cell densities in the subsamples.

For statistical evaluation of the variations in toxin composition in the culture strains, we performed hierarchical cluster analysis (unweighted pair group method with arithmetic mean) using "R" software (ver. 2.10) with "pvclust" package (Suzuki \& Shimodaira 2006). Quotients of mean deviation (MD) and standard deviation (SD) of relative frequency (\%) of PSP components in the culture strains were used in the dataset for the cluster analysis. Hierarchical clusterings were performed according to multi-scale bootstrap resampling (Shimodaira 2002) (number of resam-

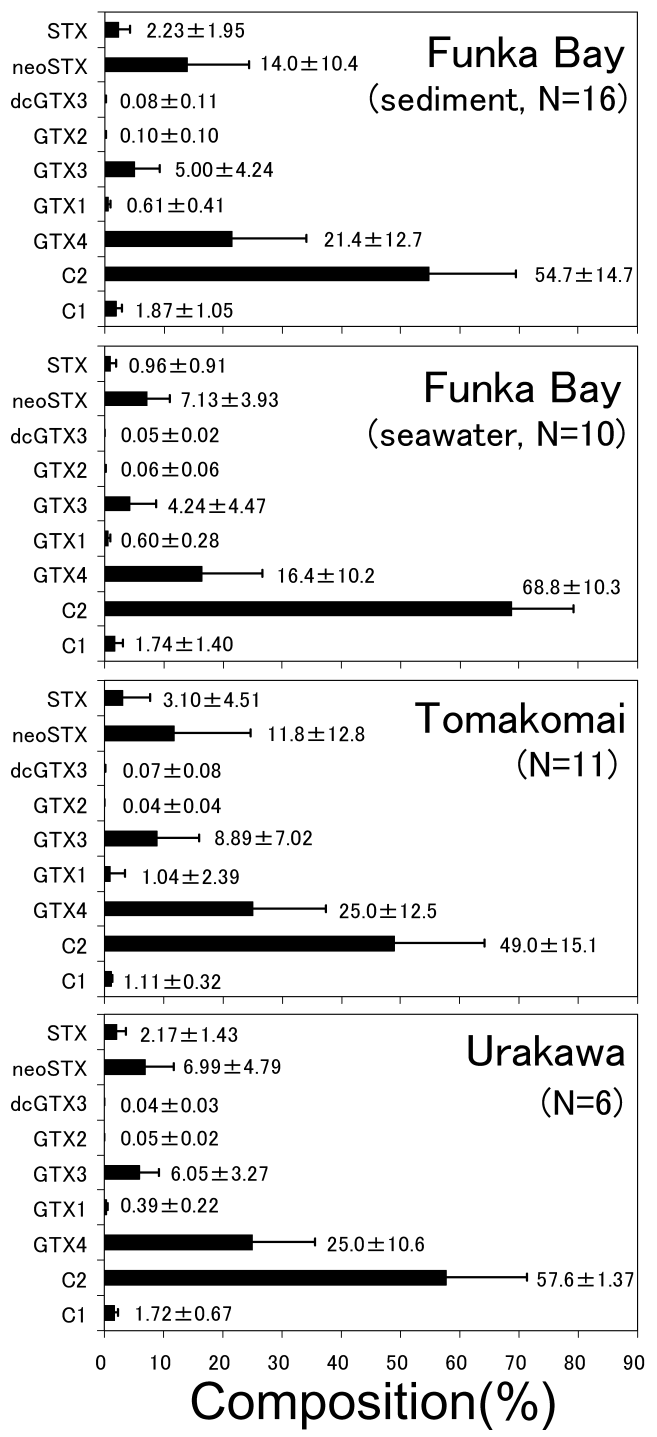

plings $=1,000)$. We recognized that the clusters with approximately unbiased $p$-values (AU) larger than $95 \%$ consist of culture strains with similar toxin profiles.

To analyze the relationship between the cell density and the cellular toxin content of the culture strains, power function curve fitting was performed using the least squares fitting method. Statistical significance of the regression equation was examined using Spearman's rank correlation coefficient $\left(r_{s}\right)$.

\section{Results}

The average composition of PSP in the culture strains of Alexandrium tamarense obtained from six areas are shown in Fig. 2. The culture strains of $A$. tamarense obtained from all areas contained $\mathrm{C} 2$, gonyautoxin 4 (GTX4), neoSTX

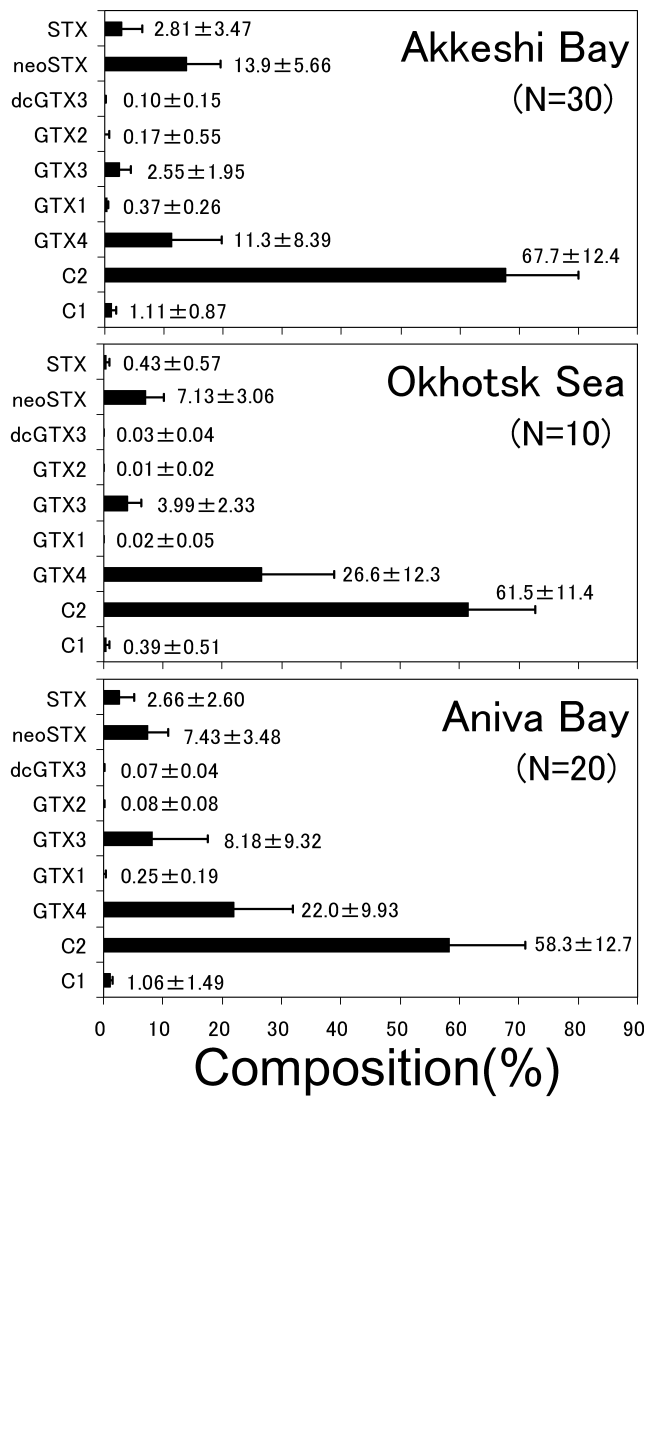

Fig. 2. Average composition of paralytic shellfish poison (mean \pm standard deviation) in the culture strains of Alexandrium tamarense obtained from the six sampling areas. Error bars indicate standard deviation. "N" mean number of culture strains. Results of the culture strains obtained from bottom sediment and seawater in Funka Bay are described separately. 
and gonyautoxin 3 (GTX3) as the major components and $\mathrm{C} 1$, gonyautoxin 1 (GTX1), gonyautoxin 2 (GTX2), decarbamoyl-gonyautoxin 3 (dcGTX3) and STX as the minor components. The results of the cluster analysis of the PSP compositions in the culture strains are shown in Fig. 3. The PSP compositions of the culture strains were respectively classified into a single cluster that shows the toxin composition as detailed above, while excluding only two culture strains (approximately unbiased $p$-value $=99 \%$ ). The toxin compositions of the two culture strains outside the cluster resembled the other cultures with respect to the major toxin components (C2, GTX4, neoSTX), though AKS-10 (from Akkeshi Bay) contained minimal GTX3 and STX, and TMS-09 (from Tomakomai) had a relatively high content of STX (Fig. 4). From these results, it is clear that the toxin compositions of the vegetative cells of $A$. tamarense obtained from the six areas in Hokkaido and southern Sakhalin can be classified into a single group with only a few exceptions.

The relationship between the cell density and the cellular toxin content of the culture strains of $A$. tamarense is shown in Fig. 5. Cellular toxin contents of the culture strains varied from 1 to $1128 \mathrm{fmol} \mathrm{cell}^{-1}$ and the cellular toxin content $\left(\mathrm{y} \mathrm{fmol} \mathrm{cell}{ }^{-1}\right.$ ) was inversely proportional to the cell density $\left(\mathrm{x}\right.$ cells $\left.\mathrm{mL}^{-1}\right)\left(\mathrm{y}=9942.2 \mathrm{x}^{-0.448}\right.$, Spearman's rank correlation coefficient: $\left.r_{s}=0.539, p<0.01\right)$. A clear inverse relationship was found between cell density and cellar toxin contents, with extremely high cellular toxin levels at low cell densities.

\section{Discussion}

The present study tried to clarify and compare the PSP profiles of vegetative cells of Alexandrium tamarense obtained from six areas around Hokkaido and Sakhalin. It has been reported that the culture duration for germination of the cysts of $A$. tamarense is ca. 10 days (Miyazono 2002a) and the maximum cell division rate is ca. 0.4 division day $^{-1}$ (Miyazono 2002b) under the same conditions as in the present study. It is therefore quite likely that the vegetative cells obtained in the culture for two weeks can be considered to be cells germinated from different cysts and are therefore a wide enough sample to be representative of sediment samples obtained from the six areas because the culture duration in the present study was probably not long enough for cell division in A. tamarense. On the other hand, considering the similar toxin compositions of the culture strains obtained from sediments and seawater in Funka Bay (Fig 2), the toxin compositions of the culture strains from sediments are a good representation of the regional characters in the six areas. Therefore, according to the results of the present study it is reasonable to conclude that the PSP profiles of culture strains of $A$. tamarense obtained from the six areas around Hokkaido and Sakhalin were almost the same.

The toxin compositions in the present study resembled

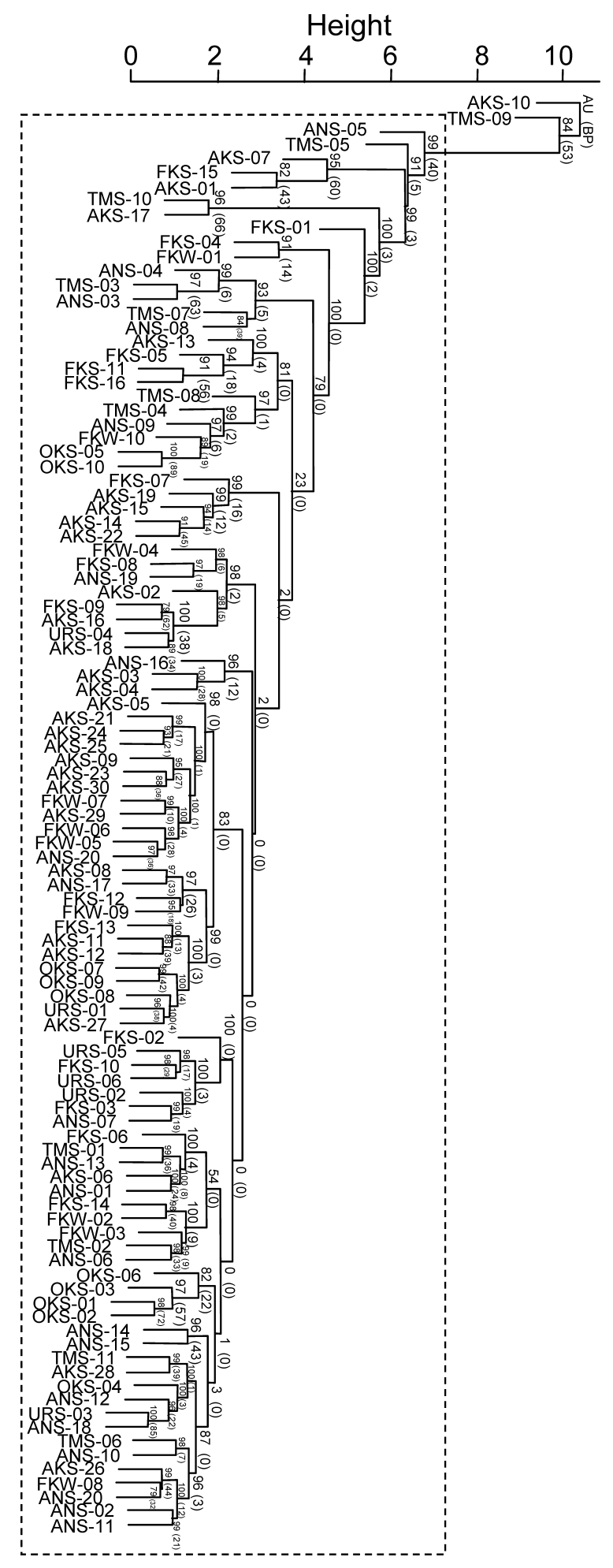

Fig. 3. Result of cluster analysis of the paralytic shellfish poison compositions of the 103 culture strains. Clusters with approximately unbiased $p$-values larger than $95 \%$ are highlighted by a broken-line rectangle, which are strongly supported by the data. "AU" and "(BP)" on the edges of the clustering mean approximately unbiased $p$-values and bootstrap probabilities (number of resamplings $=1,000$ ). "Height" on the scale on the top indicates branch length of the dendrogram. 


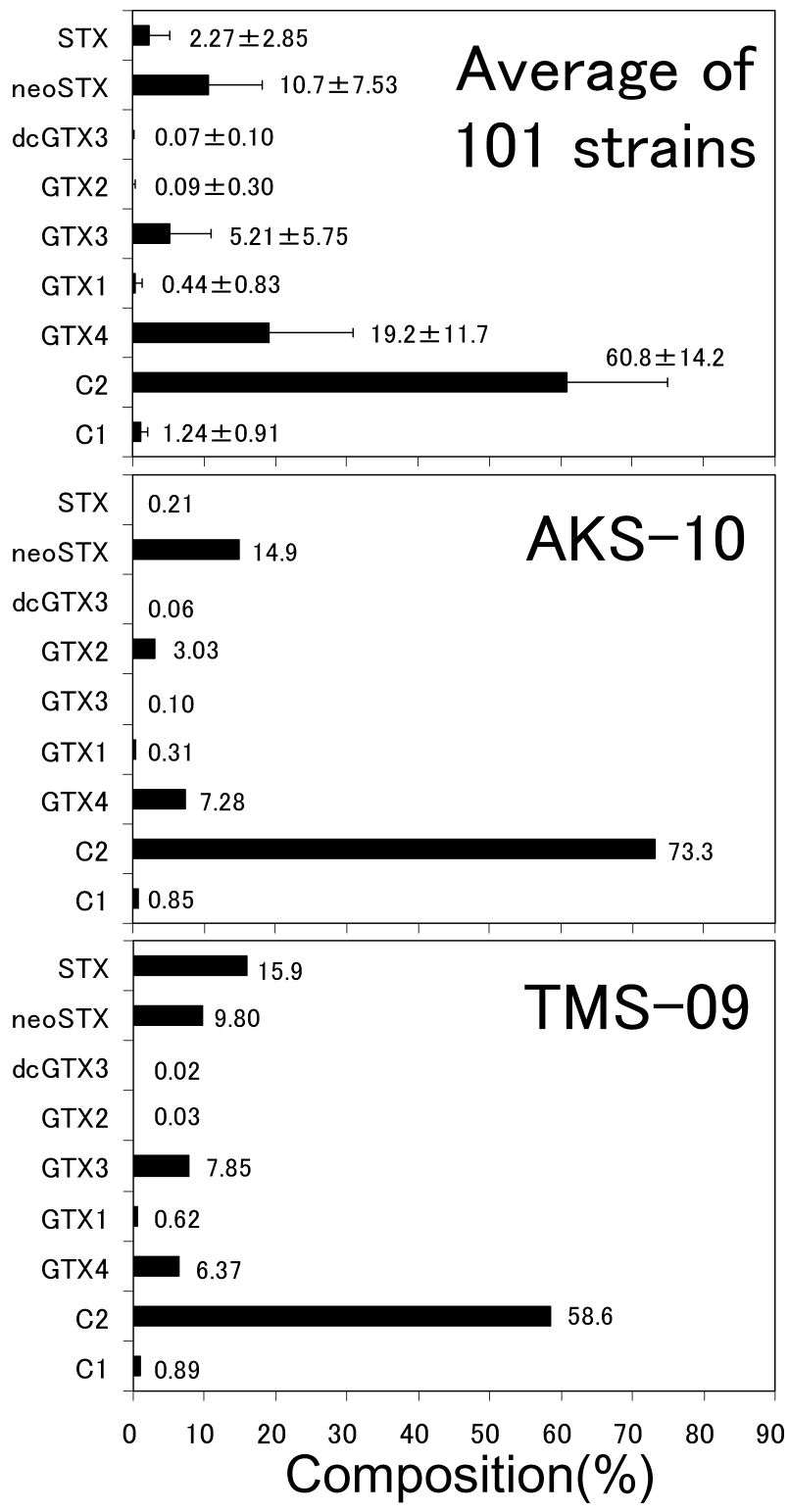

Fig. 4. Paralytic shellfish poison compositions of the 101 culture strains in the clusters highlighted by the rectangle in Fig. 3 on average (mean \pm standard deviation) and 2 culture strains (AKS-10 and TMS-09) outside the clusters.

those in the reports for southern Sakhalin (Orlova et al. 2007), Iwate Prefecture (Kaga et al. 2006), Sendai Bay (Ichimi et al. 2002) and Hiroshima Bay (Asakawa et al. $2005)$ with respect to the four major toxin contents (C2, GTX4, neoSTX and GTX3). These results suggest that the toxin compositions of $A$. tamarense are almost the same throughout Japan, though several different populations were found using microsatellite markers (Nagai et al. 2007) and the populations might be supposed to show different toxin compositions.

If $A$. tamarense have almost the same toxin compositions, it is reasonable to expect that the toxin composition accumulated in bivalves may reflect the typical toxin profile

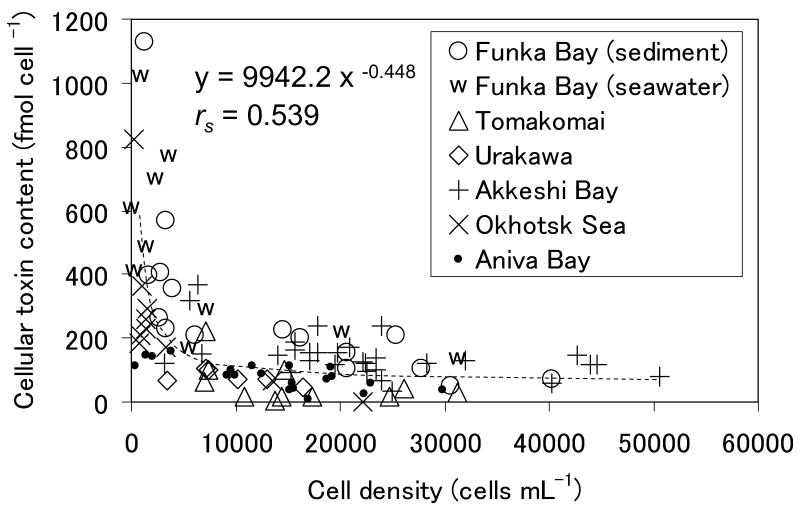

Fig. 5. Relationship between the cell density (cells $\mathrm{mL}^{-1}$ ) and the cellular toxin content ( $\mathrm{fmol} \mathrm{cell}^{-1}$ ) of the culture strains of Alexandrium tamarense. Scatter diagram is plotted using different symbols to distinguish among the sources of the samples. Regression equation of curve fitting with Spearman's rank correlation coefficient $\left(r_{s}\right)$ is described on the left side of the diagram.

of $A$. tamarense. It has been reported that the unstable $\beta$ epimer (C2, GTX4 and GTX3) in A. tamarense is gradually transformed into the $\alpha$-epimer (C1, GTX1 and GTX2) in bivalves while the equilibrium point of the $\alpha / \beta$ ratio was 3 (Oshima et al. 1992). Takata et al. (2004) found the transformation from $\beta$-epimer into $\alpha$-epimer in three bivalve species, oyster (Crassostrea gigas (Thunberg)), scallop (Mizuhopecten yessoensis (Jay)) and mussel (Mytilus edulis Linnaeus) in Kure Bay (Hiroshima Prefecture, western Japan), while the quantity of the toxin accumulated among bivalve species varied remarkably (scallop $>$ mussel $>$ oyster). Similarly, Murakami et al. (1998) reported that $\alpha$ epimer was accumulated in surf clam (Pseudocardium sachalinense (Sehrenck)) in addition to the $\beta$-epimer in Kashima Nada, Ibaraki Prefecture, eastern Japan. In Funka Bay, it was reported that the major toxin contents of PSPinfested scallop were GTX1, GTX2, GTX3, GTX4, STX and neoSTX, while C-toxins were not analyzed (Asakawa \& Takagi 1983). Considering the present results and those of previous studies, it can be assumed that bivalves generally accumulate $\beta$-epimer (C2, GTX4 and GTX3), $\alpha$ epimer (C1, GTX1 and GTX2) and neoSTX as their major toxin contents when PSP infestation of bivalves by $A$. tamarense occurs in Hokkaido. On the other hand, PSP infestation of bivalves by Alexandrium catenella (Whedon et Kofoid) Balech has occurred in Funka Bay in autumn 1988 (Noguchi et al. 1990). It has been reported that the major toxin contents of $A$. catenella from northern Japan are C2 and neoSTX (Oshima et al. 1990, Noguchi et al. 1990, Kaga et al. 2006). Oshima et al. (1990) found that the major toxin contents of scallop infested with $A$. catenella were C1, neoSTX and C2 in Funka Bay in 1988. If PSP infestation of bivalves by $A$. catenella occurs, it can be supposed that the bivalves will accumulate $\mathrm{C} 1$ ( $\alpha$-epimer of $\mathrm{C} 2), \mathrm{C} 2$ and neoSTX as the major toxin contents, differing from 
those of $A$. tamarense. Thus the results of the present study are useful to deduce the causative organism based on the toxin composition in bivalves.

The present study elucidated that the cellular toxin content ( $\mathrm{y}$ fmol cell ${ }^{-1}$ ) of $A$. tamarense was inversely proportional to the cell density $\left(\mathrm{x}\right.$ cells $\left.\mathrm{mL}^{-1}\right)\left(\mathrm{y}=9942.2 \mathrm{x}^{-0.448}\right)$. This result suggests that a vegetative cell in a low cell density environment $\left(10^{-2}-10 \mathrm{~mL}^{-1}\right)$ as usually found in situ has a very high toxicity (approx. $\geqq 10^{4} \mathrm{fmol} \mathrm{cell}^{-1}$ ). Oshima et al. (1990) found that the cellular toxin content of $A$. tamarense collected from Funka Bay fluctuated from 35 to $280 \mathrm{fmol} \mathrm{cell}^{-1}$ during the culture experiment. Sakamoto \& Kotani (1998) pointed out that the cellular toxin content of $A$. tamarense obtained from Kure Bay became higher at lower cell densities. In addition, Matsuda et al. (2006) elucidated that the cellular toxin content of $A$. catenella was much higher in the culture experiment under phosphate stress applied for maintaining a low growth rate. Our result supports these previous studies showing that the cellular toxin content of $A$. tamarense fluctuates with the cell density in culture experiments. However, there have been no reports published to date about high toxin content $\left(>10^{3}\right.$ fmol cell ${ }^{-1}$ ) in clone cultures of $A$. tamarense such as found in the present study. To explain the high toxin production of the several culture strains in our study, it seems necessary to examine the genetic character of the culture strains. Oh et al. (2010) reported that PSP contents of the culture strains of Gymnodinium catenatum Graham ranged between 56.6 and $740 \mathrm{fmol} \mathrm{cell}^{-1}$ in Inokushi Bay (Ooita Prefecture, western Japan) and some strains with different toxin profiles probably originated from other areas. This report suggested that research initiatives are needed to investigate the population structure based on molecular biological methods. Genetic studies on high-toxicity strains of $A$. tamarense should be done in the near future. Nishihama (1982) reported that a bloom (approx. $10^{3}$ cells $\mathrm{L}^{-1}$ ) of $A$. tamarense occurred and the PSP toxicity of cultured scallop drastically increased to 550 mouse unit $\mathrm{g}^{-1}$ digestive diverticula in only two weeks in Funka Bay in 1979. The mechanism of PSP infestation in such a case can be partially explained by assuming that, as found in the present study, vegetative cells of $A$. tamarense in situ may have extremely high toxicity (approx. $\geqq 10^{4} \mathrm{fmol} \mathrm{cell}{ }^{-1}$ ). However, there are no previous reports about the occurrence of high-toxicity cells of $A$. tamarense with a cellular toxin content of $10^{4} \mathrm{fmol}_{\text {cells }}{ }^{-1}$ along the coast of Japan. White (1986) estimated that the cellular toxin content of Gonyaulax excavata (Braarud) Balech (=A. tamarense) collected in situ ranged from $2.7 \times 10^{-6}$ to $1.1 \times 10^{-3} \mu \mathrm{g} \mathrm{STX} \mathrm{cells}{ }^{-1}$, which can be converted to "from $9.0 \times 10^{-6}$ to $3.7 \times 10^{-3}$ nmol STX cells ${ }^{-1}$, in the Bay of Fundy, southeastern Canada. This highest toxicity value is the only instance reported of the occurrence of $A$. tamarense with such high toxicity, namely approximately 10 times larger than the highest cellular toxin content in our results. It is necessary to prove the occurrence of $A$. tamarense with high toxicities such as in our assumption and the report of White (1986), in the coastal waters in Japan through in situ sampling, and to analyze the cellular toxin content of $A$. tamarense in the future.

\section{Acknowledgments}

We are grateful to the captains and crews of the $\mathrm{R} / \mathrm{V}$ Hokuyo Maru and R/V Kinsei Maru for kindly helping with the sampling. We also thank colleagues at the Hokkaido Fishery Experiment Station for their helpful comments.

\section{References}

Asakawa M, Takagi M (1983) PSP components of toxic scallops from Funka Bay in comparison with those of Protogonyaulax tamarensis. Bull Fac Fish Hokkaido Univ 34: 140-147. (in Japanese with English abstract)

Asakawa M, Takayama H, Beppu R, Miyazawa K (2005) Occurrence of paralytic shellfish poison (PSP)-producing dinoflagellate Alexandrium tamarense in Hiroshima Bay, Hiroshima Prefecture, Japan, during 1993-2004 and its PSP profiles. J Food Hyg Soc Jpn, 46: 246-250.

Balech E (1995) The genus Alexandrium Halim (Dinoflagellata). Sherkin Island Marine Station Publication, Sherkin Island, Co. Cork, Ireland, $151 \mathrm{pp}$.

Fritz L, Triemer RE (1985) A rapid simple technique utilizing calcofluor white M2R for the visualization of dinoflagellate thecal plates. J Phycol 21: 662-664.

Hallegraeff GM (1993) A review of harmful algal blooms and their apparent global increase. Phycologia 32: 79-99.

Hallegraeff GM (1995) 1. Harmful algal blooms: A global overview In: Manual on Harmful Marine Microalgae (eds Hallegraeff GM, Anderson DM, Cembella AD). UNESCO, Paris, pp 391-396.

Ichimi K, Suzuki T, Ito A (2002) Variety of PSP toxin profiles in various culture strains of Alexandrium tamarense and change of toxin profile in natural $A$. tamarense population. J Exp Mar Biol Ecol 273: 51-60.

Kaga S, Sekiguchi K, Yoshida M, Ogata T (2006) Occurrence and toxin production of Alexandrium spp. (Dinophyceae) in coastal waters of Iwate Prefecture, Japan. Nippon Suisan Gakkaishi 72: 1068-1076. (in Japanese with English abstract)

Matsuda A, Nishijima T, Fukami K, Adachi M (2006) Growth kinetics and paralytic shellfish poisoning toxin production in phosphorous-limited cultures of Alexandrium catenella. Nippon Suisan Gakkaishi 72: 193-200. (in Japanese with English abstract)

Miyazono (2002a) Effects of water temperature and irradiance conditions on the growth of the toxic dinoflagellate Alexandrium tamarense isolated from Funka Bay. Sci Rep Hokkaido Fish Exp Stn 61: 1-8. (in Japanese with English abstract)

Miyazono (2002b) Vertical distribution, germination activity and seasonal density variations of cysts of the toxic dinoflagellate, Alexandrium tamarense in Funka Bay. Sci Rep Hokkaido Fish Exp Stn 61: 9-15. (in Japanese with English abstract)

Murakami R, Yamamoto K, Noguchi T (1998) Toxicity of the bi- 
valves toxificated with paralytic shellfish poison (PSP) in Ibaraki, Japan. Bull Fac Fish Nagasaki Univ 79: 37-41. (in Japanese with English abstract)

Nagai S, Lian C, Yamaguchi S, Hamaguchi M, Matsuyama Y, Itakura S, Shimada H, Kaga S, Yamauchi H, Sonda Y, Nishikawa T, Kim CH, Hogetsu T (2007) Microsatellite markers reveal population genetic structure of the toxic dinoflagellate Alexandrium tamarense (Dinophyceae) in Japanese coastal waters. J Phycol 43: 43-54.

Nishihama Y (1982) Seasonal abundance of Protogonyaulax sp. causing paralytic shellfish poisoning in Funka Bay. In: Proceeding of North Pacific Aquaculture Symposium (eds Melteff BR, Neve RA). Alaska Sea Grant Publication, Anchorage, pp. 319-327.

Noguchi T, Asakawa M, Arakawa O, Fukuyo Y, Nishio S, Tanno K, Hashimoto K (1990) First occurrence of Alexandrium catenella in Funka Bay, Hokkaido, along with its unique toxin composition. In: Toxic Marine Phytoplankton (eds Graneli E, Sundstrom B, Edler L, Anderson DM). Elsevier Science Publishing, New York, pp 493-498.

Oh SJ, Matsuyama Y, Yoon YH, Miyamura K, Choi CG, Yang H-S, Kang IJ (2010) Comparative analysis of paralytic shellfish toxin content and profile produced by dinoflagellate Gymnodinium catenatum isolated from Inokushi Bay, Japan. J Fac Agr Kyushu Univ. 55: 47-54.

Orlova TY, Selina MS, Lilly EL, Kulis DM, Anderson DM (2007) Morphogenetic and toxin composition variability of Alexandrium tamarense (Dinophyceae) from the east coast of Russia. Phycologia 46: 534-548.

Oshima Y (1995) Post-column derivatization HPLC methods for paralytic shellfish poisons. In: Manual on Harmful Marine Microalgae (eds Hallegraeff GM, Anderson DM, Cembella AD). UNESCO, Paris, pp. 81-94.

Oshima Y, Bolch CJ, Hallegraeff GM (1992) Toxin composition of resting cysts of Alexandrium tamarense (Dinophyceae). Toxicon 30: 1539-1544.

Oshima Y, Sugino H, Itakura H, Hirota M, Yasumoto T (1990) Comparative studies on paralytic shellfish toxin profile of dinoflagellates and bivalves. In: Toxic Marine Phytoplankton (eds Graneli E, Sundstrom B, Edler L, Anderson DM). Elsevier Science Publishing, New York, pp 391-396.

Sakamoto S, Kotani Y (1998) Variation of paralytic shellfish toxin contents and composition in Alexandrium tamarense collected at Kure Bay, Hiroshima Prefecture. Bull Nansei Natl Fish Res Inst 31: 45-52. (in Japanese with English abstract)

Sako Y, Kim CH, Ninomiya H, Adachi M, Ishida Y (1990) Isozyme and cross analysis of mating populations in the Alexandrium catenella / tamarense species complex. In: Toxic Marine Phytoplankton (eds Graneli E, Sundstrom B, Edler L, Anderson DM). Elsevier Science Publishing, New York, pp 320-323.

Sako Y, Naya N, Yoshida T, Kim CH, Uchida A, Ishida Y (1995) Studies on stability and heredity of PSP toxin composition in the toxic dinoflagellate Alexandrium. In: Harmful Marine Algal Blooms (eds Lassus P, Arzul G, Erard E, Gentien P, Marcaillou C). Lavoisier Publishing, Paris, pp 401-406.

Shimada H, Miyazono A (2005) Horizontal distribution of toxic Alexandrium spp. (Dinophyceae) resting cysts around Hokkaido, Japan. Plankton Biol Ecol 52: 76-84.

Shimada H, Sawada M, Kuribayashi T, Nakata A, Miyazono A, Asami H (2010) Spatial distribution of the toxic dinoflagellate Alexandrium tamarense in summer in the Okhotsk Sea off Hokkaido, Japan. Plankton Benthos Res 5(1): 1-10.

Shimodaira H (2002). An approximately unbiased test of phylogenetic tree selection. Syst Biol 51: 492-508.

Suzuki R, Shimodaira H (2006) pvclust: an R package for assessing the uncertainty in hierarchical clustering. Bioinformatics 22: $1540-1542$.

Takata K, Seno M, Toukubo Y, Takatsuji H, Takayama H, Ogawa $\mathrm{H}$ (2004) Differences in accumulation and elimination of paralytic shellfish toxins among oyster, scallop and mussel. Nippon Suisan Gakkaishi 70: 598-606. (in Japanese with English abstract)

White AW (1986) High toxin content in the dinoflagellate Gonyaulax excavata in nature. Toxicon 24: 605-610. 